\title{
THE CARTOGRAPHIES OF PROTEST
}

Pollyanna Rutz

SCHOOL OF MEDLA, FILM AND MUSIC, UNIVERSITY OF SUSSEX

\begin{abstract}
In The Practice of Everyday Life, de Certeau likens himself to a Solar Eye reading the city spread out like a text below. He compares this all-seeing position to the enmeshed position of those whose intermingled footsteps pass through the city streets, writing stories that deliberately elude legibility. These two ways of experiencing the city offer a theoretical frame through which I will explore both the administration of protest spaces, and protesters' ongoing attempts to subvert and evade those controls. In doing so, this contribution will examine the way in which the police practice of kettling depends upon the police's ability to draw a series of distinctions between 'good' protesters who comply with state demands, and 'bad' protesters who err from official routes. It will go onto to explore the way in which the practice of maptivism impacts upon protesters' ability to occupy city spaces and resist the totalising administrations of the state.
\end{abstract}

\section{Keywords}

Protest; kettling; cartographies; The City; police 
$\mathrm{P}_{\mathrm{T}}^{\mathrm{s}}$ ublic demonstrations move people and their ideas from the margins to the mainstream. Thus, when protesters converge on sites of national or global significance, such as St Paul's Cathedral in London, the Zócalo in Mexico City or Tahrir Square in Cairo, they attempt to illustrate both their own lack of a place within the status quo and to offer alternative political positions to a wider public. Consequently, these city spaces become a site of both physical and ideological struggle, between those 'legitimising what is already known' (Foucault cited in Patton, 2000: 25) and those trying to offer the mainstream 'a glimpse of what is possible...a utopia defined not as a no-place but as this-place' (Notes From Nowhere Collective, 2003: 182).

In The Practice of Everyday Life, de Certeau describes the act of 'physically moving about' the city as having the itinerant function of yesterday's or today's superstitions' (1984: 106). This understanding of protest as an expression of placelessness can be further developed by turning to Mary Douglas' work Purity and Danger. In this book she argues that the arrival of marginal groups into collective or community spaces disrupts pre-existing orders. She goes on to suggest that such external threats require a particular set of cleansing responses from 'persons representing the formal structure' (2002: 1060). This is a role that in mature western democracies is fulfilled by the police, who are charged with the maintenance of social, and therefore by implication political, order (Reiner, 2000: 8).

This article will offer an alternative reading of the dynamic between more traditional activists who are willing to engage with the police and autonomous activists who are not. It will begin by drawing on de Certeau and exploring the different ways in which mass demonstrations can be read. It will go on to examine the way in which the police practice of kettling acts as a 'filtering mechanism' (Douglas, 2002: 38) that produces a series of distinctions between 'good' protesters who comply with state demands, and 'bad' protesters who err from official routes. Finally, it will explore the ways in which the practice of maptivism redresses the imbalance of informational power between protesters and police, and asks whether such web applications currently contribute to the ability of protesters to resist the totalising administrations of the state.

\section{Reading Mass Demonstrations}

I'd like to begin by recalling De Certeau standing at the top of the World Trade Centre gazing down on Manhattan spread out below. According to de Certeau, the city seen from above 'provides a way of conceiving and constructing space on the basis of a finite number of stable, isolatable and interconnected properties' (1984: 94). In other words, it imposes order upon the 'ordinary practitioners' who live 'below the thresholds at which visibility begins' (1984: 93). Consequently, he likens himself to Icarus and describes the way in which the doomed boy's flight turned him into an all-seeing, all-knowing 'solar Eye' and writes:

His elevation transfigures him into a voyeur; it puts him at a distance. It transforms the bewitching world by which one was 'possessed' into a text that lies before one's eyes. It allows one to read it, to be a solar eye looking down like a God. (1984: 92)

De Certeau argues that this elevated position enables him to read the city as if it were a text. However, he points out that this understanding of the city is ultimately a pleasurable 'misunderstanding' (1984: 93). He suggests that by relinquishing the privileges offered by the solar eye and 'stepping in through proportions, sequences, and intensities which vary according to the time, the path taken and the walker' (2004: 99) one can immerse oneself within a differently experienced city space. This requires one to adopt a far more uncomfortable in-the- 
middle position, which entangles and enmeshes the walker within the 'murky intertwining daily behaviours' of the proliferating inhabitants below (1984: 93). He goes on to suggest that their entangled routes through the urban landscape constitutes an 'unrecognised poem in which each body is an element signed by many others’ but which eludes legibility (de Certeau, 1984: 93).

This topological view is further developed by the parallel between traversing textual space and actual space. De Certeau asserts that the 'act of walking is to the urban city what the speech act is to language' (1998: 97). In this way he makes a connection between seeing and reading, walking and writing. De Certeau's approach has been developed into the notion of third space. In his influential article, Soja describes third space as an 'open ended set of defining moments' (1996: 260), a space that is 'creatively open to redefinition and expansion in new directions' (1996: 2). Routledge extends the notion by reflecting on the overlapping intersections in third space and upon the 'coming and going in a borderline zone between different modes of action' (1996: 406). These are spaces in which a 'unity of experience' (Douglas, 2002: 4) has been purposefully relinquished in favour of the potential inherent in disordered transitional states.

I would suggest that the notion of the city as a text read from above, but written from within, offers a particularly helpful way of thinking about how we experience the construction of protest. I begin by examining demonstrations that are represented as peaceful and legitimate occupations of city spaces. Traditional demonstrations, such as those now organised by institutionalised protest organisations are invariably headed by a movement's most vocal and recognisable members. These leaders usually carry a large banner, which articulates activists' principal demands and titles the demonstration. This provides onlookers with a politically clear and unambiguous focal point. This group is usually followed by a large number of more anonymous protesters who are frequently broken up into smaller sub-sections or 'chapters' by banners proclaiming membership of a particular group or organisation. These sub-sections tend to mirror the hierarchies of the demonstration as a whole. Thus they are headed by the most committed local activists who are then followed by less active core supporters. This leaves a non-affiliated mass of individuals to demonstrate popular support, wave placards and generally bring up the rear.

One could argue that traditionally organised demonstrations are remarkably print-based. They spread out before the viewer and, like the city seen from above, can be read like printed texts. They have a linear narrative, which has been carefully credited, titled and broken up into more or less discrete and manageable chapters. Like a newspaper, their intent can be grasped by scanning the banners/headlines that lead the columns of marchers/print. Political ends are articulated via banners, placards and flyers that spell out the protesters' demands. This emphasis on text has important political implications. Ong points out that the 'mindset' characteristic of print culture creates a sense of personal disengagement from 'the arena where human beings struggle with one and other' (Ong, 1982: 43). If one applies Ong's notion of a print mindset to the march, then activists taking part in traditionally organised demonstrations cannot 'actualise' their own route through the 'constructed order' (de Certeau, 1984: 93). Instead, activists are required/permitted to do little more than walk the pre-arranged route, echo the pre-chosen chants and listen to the prepared speeches.

Similarly an individual watching the demonstration pass by (who is, let's not forget, a potential activist) is placed in a removed and excluded position. Like de Certeau on top of the World Trade Centre they read a coherent and pleasing, but in many ways 'fictional', account of the political terrain spread out before them (de Certeau, 1984: 93). In smoothing out the contradictory uncertainties of most protest movements, these sorts of demonstrations offer a 'semblance of order' (Douglas, 2002: 4) that can be misleading. This is a view which stills the 'opaque mobility' of the city/text, creating a sense of god-like euphoria, but it is also, as Icarus 
discovered, both temporary and misguided. In this way, both the marchers and the observers occupy a politically distanced and potentially mistaken position in relation to traditionally organised mass demonstrations.

The structural systems of traditionally organised demonstrations seem to encourage, even require, activists to be the passive element in the producer/consumer binary. For many activists this sense of closure has depressing political implications in that it removes the individual from the everyday struggles of the life-world, making politics appear both alien (it's nothing to do with me) and unalterable (I can't do anything about it anyway). As a result, many autonomous protesters argue that traditional demonstrations are 'essentially' a form of 'lobbying en masse' (Black block protesters, no date). These debates began to circulate through activist circles in the build up to the very large-scale summit demonstrations that characterised the early days of the anti-globalisation movement and are still shaping autonomous protest today (Ruiz, 2014).

The police are keen to facilitate mass demonstrations in an attempt to maintain a reputation as fair and even-handed managers of legitimate protest. Waddington argues that this had led to protest becoming increasingly institutionalised in such a way as to severely limit the impact protesters can make upon the mainstream's political consciousness (1998). Thus, for example, the route of many marches takes protesters away from the most populated areas of a city. Similarly, city centre marches tend to be scheduled in such a way as to avoid peak periods in the day such as rush hour. Consequently, one could argue that by utilising the quietest roads and hours, traditionally organised demonstrations purposefully keep protesters out of the public eye, ensuring that the articulation of dissent does not disrupt the patterns and rhythms of everyday city life. This lends credibility to autonomous activists' belief that protest is permitted, sometimes even encouraged, but only on the proviso that it does not actually impact on the day to day workings of city life (Reiner, 1998: 47).

Protesters' sense of being, at best, managed within and, at worst, excluded from, mainstream public arenas (Gitlin, 2003, Holleran et al, 1970) has led autonomous activists to challenge many of the structures that shape public demonstrations. While such organisations are obliged by law ${ }^{1}$ to inform the police of their intent to demonstrate, autonomous activists usually refuse to enter into any of the usual pre-demonstration collaborations. They justify this position by claiming that their rejection of hierarchies and bureaucracies render them organisationally incapable of engaging with the police as they do not have leaders/spokespersons/liaison officers to conduct negotiations on the behalf of the wider collective (unnamed protester, J18, 1999).

This refusal to negotiate with the police has a significant impact on the way in which autonomous protests produce themselves on the ground. As previously discussed, conventionally organised demonstrations offer onlookers a solar eye view of an unfolding, but predetermined, political narrative. Autonomously organised demonstrations, on the other hand, refuse to rank or prioritise the political positions available to individual protesters. Consequently, the familiar givens of a traditionally organised march are replaced by a sprawling ebb and flow of protest clusters, which emerge and dissolve, repeatedly and at random, throughout the day and across the city. This creates a demonstrative space in which participants, spectators and the police are all immersed in the murky in-between spaces of political struggle.

These demonstrative third spaces deny protesters the sense of security and direction offered by traditional political organisations. They exist at 'ground level' and are composed by a myriad of 'footsteps' that 'cannot be counted because each unit has a qualitative character: a style of tactile apprehension and kinaesthetic appropriation (De Certeau, 1984: 97). They are constituted by the

1 According to British law activists must 'notify' police of their intent to demonstrate at least six days prior to the proposed event. 
unexpected and potentially transformative ways in which different types of people combine with differently constructed places. In this way they require individual protesters to produce their own political position, via the links and connections they make with the people/materials around them (Moles, 2008). Thus, rather than consuming the city from above, autonomous protesters weave through the city streets creating the 'thicks and thins of an urban 'text' they write without being able to read' (de Certeau, 1984: 93).

Equally significantly, this type of space refuses to be read easily and requires observers passers by, the police and journalists - to actively participate in the construction of meaning. Thus, while traditionally organised demonstrations lead the reader along a predetermined route through the city, autonomous demonstrations' refusal to offer a preferred route deliberately deprives the observer of an enticing (albeit fictional) understanding of the demonstration. Instead, it requires them to engage in the effort of producing their own partial but embedded reading of the demonstration and the context within which it exists. Consequently, while these demonstrations are inevitably structured by a wider societal power dynamic, they are also polysemic and open to multiple interpretations (Hall, 1974).

In summary, traditionally organised demonstrations are characterised by an ordered and segmented flow, which allows them to coincide with the equally administered city spaces that surround them. In contrast, autonomous protesters' rejection of hierarchical top-down organisational structures in favour of more flexible, horizontal communication systems, creates demonstrative spaces which are in a perpetual state of flux. This produces a dynamic in which the city streets can be represented as a site of contest between differently organised protest groupings, such as those committed to non-violent direct action and those who advocate more confrontational forms of civil disobedience, as well as between protesters and police.

\section{Polly put the kettle on...}

The 'gleeful delight' taken by autonomous protesters in the wilful 'scrambling of conventional categories' (Graeber, 2004: 209) is problematic for those charged with the maintenance of public order. Autonomous protesters' refusal to enter into pre-demonstration negotiations with the police has the effect of removing the temporal and spatial boundaries that usually constrain the articulation of public dissent. Moreover, the loss of orientation experienced by individuals and organisations accustomed to occupying a comfortable (but mistaken) solar eye position can trigger a reaction of panic. Consequently, the police, who are charged with maintaining order, tend to view such protests as 'solely about bringing disruption and inconvenience to the city' (Superintendent Kevin Moore cited in the Brighton and Hove Argus, 2005). Similarly, the mainstream media tends to frame autonomous demonstrations as constituting an incoherent, uncontrollable and therefore potentially dangerous threat to civil society (Donson, 2004, Stein, 2001).

The introduction of austerity measures in response to the financial crisis of 2008 has led to increased levels of civil unrest. These demonstrations are being policed at a time when there has been a significant decrease in the levels of funding allocated to the maintenance of public order. The police have responded to these challenging dynamics by relying increasingly heavily on the practice of kettling demonstrators who are refusing to actively participate in the administration of protest. Kettling is a tactic that has been used during both local and national demonstrations for a considerable number of years. The police describe kettling as 'progressively isolating problematic groups and individuals from peaceful protesters' (Policing Public Order, 2001: 7). 'Problematic' 
groups are corralled and detained, often without access to shelter, food or water, until the police ascertain that the threat to law and order has been dissipated. This tactic is perceived by activists and some human rights organisations as a 'brutal and undemocratic' attempt to repress citizens' right to protest (http://www.opensukey.org).

Kettling can be read as the moment in which the systems and structure of autonomous protesters clash with those imposed by the police and other state powers. As such, it is worth examining the processes that constitute a kettle in a little more detail. Kettling employs three interrelated policing techniques. Firstly, the police form into lines, often but not always at a crossroads or junction, which they draw up and around a moving demonstration. This has the effect of capturing, confining and then compressing protesters within an ever-decreasing space. Each of the police lines tends to be two officers thick and is supported by a number of police vans and other vehicles. In this way, leaderless marches, which had been loosely disorganised, are corralled and controlled by the imposition of a solid and intimidating police boundary.

Having imposed these boundaries on the demonstration, the police create an unbridgeable gap between the spaces inside and outside the cordoned-off area. Protesters who attempt to breach the cordon in order to talk to passers-by or hand out leaflets are prevented from doing so and pushed back into the space allocated to them. In addition, members of the public who try to remonstrate with the police on behalf of trapped protesters are physically escorted from the scene. In this way, the police impose a space of about five to ten feet between 'protesters' and 'the public', making the two groupings separated and discreet. Mingling between these different groups is disallowed.

Finally, having imposed a distinction between protesters and the public, the police frequently impose a further distinction between 'good' protesters and 'bad' protesters ${ }^{2}$. They do this by appealing to different categories of people to leave the space they have enclosed. So, for example, the police will often offer to escort the elderly or less able, as well as people with small children, beyond the police lines and into 'safe' public space. The removal of 'good' or 'ordinary' protesters alters the demographic dynamic of the demonstration considerably. It creates a homogenised space occupied only by protesters physically and emotionally strong enough to withstand the escalating tensions. Thus a space that had been creatively open to redefinition and expansion is re-categorised as a potentially contaminating threat to wider society and closed down.

The imposition of such clearly demarcated boundaries eradicates the possibility of an overlapping in-the-middle position and ensures that there can be no potentially contaminating intermingling across the previously porous boundary. The borderline zone between different modes of action identified by Routledge is simply eradicated. Consequently, the possibility of being a protester and a member of the public during an autonomous demonstration is disallowed. In this way the police can be seen to be re-ordering the city in a way which is inherently conservative in so far as it assumes that 'a stratified society is the proper natural outcome of human history as well as the underpinning of political life' (Amartrudo, 2009: 50).

This technique is particularly significant because, as Waddington (1998: 55) points out, 'patrolling the boundary of inclusion and exclusion' involves bestowing (and withholding) citizenship on the people. In doing so they guard against the dangers inherent in transitional states by creating a ritual which 'separates' the protester 'from his old status, segregates him for

2 The police force's increased reliance on kettling as a tool for maintaining public order means that variations on this practice are beginning to appear. For example, the kettle imposed upon students during the protests against tuition fees in London was so large that those in the middle of the protest were often unaware that they were being detained. On the other hand the police arrested every single one of the 286 demonstrators who had been kettled after breaking away from a Unite Against Fascism protest in 2013. 
a time and then publically declares his entry into a new status' (Douglas, 202: 97), the police are protecting pre-existing patterns of society and ensuring that protesters confirm to an 'ideal order' (Douglas, 2002: 2). Thus, the police practice of kettling is a 'filtering mechanism' that produces a particular type of protest space; one that 'forces' protesters into 'good and bad' and justifies the forceful imposition of 'order' on those who remain.

The distinction between protesters and public drawn by the police on the street is reproduced by journalists in the news. As Juras points out, the 'rebel styles, imagery and tactics' of this protest demographic have a tendency to lend themselves to dominant media frames that would construct protesters as 'deviant' (2005: 423). The police practice of kettling facilitates this type of coverage of popular demonstrations as it almost inevitably focuses the media's attention on the young and increasingly angry. Consequently, these protesters are particularly vulnerable to being delegitimized in the news, as well as on the streets, as an aggressive, antagonistic and borderline criminal 'them' whose occupation of shared material and symbolic spaces constitutes a real and present threat to the identity of the law abiding 'us' (Mouffe, 2005).

Despite anti-globalisation protesters' attempts to challenge the practice of kettling in the European Court of Human Rights in 2001, debates around the police practice of containment generally failed to gain traction within wider public arenas. However, the classification of demonstrating secondary school children in 2009 (some of whom were as young as eleven) as 'problematic', and their subsequent containment without access to food and water for more than six hours, was widely read as an example of 'indiscriminate punishment' (Bowcott, 2011). As a result, the police found themselves in a position where the tactic of kettling or containment was being retrospectively redefined by a wider public as potentially problematic (Waddington, 1998).

A small group of students from University College London responded to these events by developing an anti-kettling app called Sukey'. These students had been 'recently politicised' (Kingsley, 2011) by the violence they experienced during student demonstrations against the coalition government's introduction of tuition fees. They described Sukey as a 'multi platform news, communication and logistical support system' (http://opensukey.org), which combines information from Twitter, Facebook, SMS and RSS, to give real time information about the movements of both protesters and the police during demonstrations. Some critics in the mainstream described the website in very negative terms. For example, Tory blogger Harry Cole called Sukey a tool for rioters, tweeting 'there something disgustingly ironic about riot organising iphone app. Just about says it all about this countries kids.' (sic, cited in Kingsley, 2011). However, these views were quickly modified when it became clear that Sukey's imagined audience would be using the web app to avoid, rather than provoke, confrontation.

The Sukey team describe their aim as being:

[...] to provide peaceful protesters with up to date news that will keep them informed, assist them in avoiding injury, help them keep clear of trouble spots and avoid unnecessary injury. (Sukey, 2011)

Sukey sets out to achieve this aim by gathering information from multiple sources as a demonstration unfolds on the ground. Information is crowd-sourced from members of the public embedded in the demonstration, and other non-protesting but interested parties such as parents, the police and journalists. Once data has been gathered in this way, it is verified by members of

3 Sukey's name is taken from the well-known children's rhyme 'Polly put the kettle on', which ends with the lines 'Sukey take it off again/we all go home'. 
the Sukey team, condensed and plotted onto a map which is fed back out to protesters on the street via smartphones. Protesters on the ground can use Sukey in one of two ways. They can use it to either access a map that plots the movements of protesters and the police in real time or they can use it to access a compass ${ }^{4}$ which points to safe or hazardous protest zones. In this way Sukey enables protesters to avoid getting caught up in police kettles and other points of conflict.

The Sukey website enables people who do not know each other to act in concert because they 'carry devices that possess both communication and computing capabilities' (Rheingold, 2000: 191). Moreover, in doing so it creates an interlinked network of strong and weak ties (Latour, 1999, McAdam, 1999) which redresses the imbalance of information between police and protesters, and allows protesters ${ }^{5}$ to actively participate in the construction of the demonstration they constitute on the ground whilst also being able to 'see what's going on around them' (http:// beyondclicktivism.com) from above. As such, protesters with access to Sukey occupy both an enmeshed, in-the-middle position 'below the threshold at which visibility begins' and an elevated, all-seeing 'solar eye' position (de Certeau, 1984: 92).

These types of information networks are particularly significant when one compares them to the far more rigid and inflexible communications structures utilised by the police force. While the police enjoy access to a communications network that includes aerial surveillance units, closed-circuit television cameras and forward intelligence teams, their communications systems remain distinctly hierarchical and organisationally bound (HMIC, 2011). The police force's communication networks allows commanders to communicate clearly with police officers on the ground but does not facilitate horizontal communication between different police officers on the streets or the wider public. Thus, while the police enjoy a solar eye view of a demonstration, they are far removed from the communicative ebb and flow experienced by those walking through the city streets.

Sukey appears to be part of the empowering groundswell of technology-driven tools, which have transformed the nature of protest (for example, blogger Dominic Fox describes Sukey as 'a kind of emblem of organization, a statement of intent' (2011). This understanding of new information technologies in general, and social networking in particular, underpins many popular debates around events such as the Arab Spring (Rheingold, 2000). Such technologically deterministic narratives suggest that the affordances of new communications systems are the salvation, or alternatively the ruin, of our otherwise ailing democratic process. This analysis recognizes the organisational potential of digital communication (Bennett and Segerberger, 2012) and appears to substantiate the more abstract accounts of networked power put forward by scholars such as Castells (2007) and Benkler (2006).

These narrative frames have much in common with those used to frame activists' use of the Internet in the late 1990's. Indymedia, for example, was seen by many as the power behind the antiglobalisation movement which was itself described as 'web-like' (Viner, 2000). Both Indymedia and Sukey emerged in response to a protest environment shaped by a particular moment in the unfolding dynamics of neo-liberal globalisation. In both cases, connections were made between technological affordances offered by new technologies and an implied 'interior transformation of consciousness' (Ong, 1982: 82) that challenges top down communication flows. However, Sukey is different from Indymedia in a number of significant ways.

Indymedia perceives itself to be the teller of 'radical, accurate and passionate' truths (http://

4 The compass application took longer than anticipated to code and was therefore not initially available to protesters.

5 It's worth noting that some protesters do not have access to smartphones and that other more surveillance savvy protesters may choose to leave their mobile phones at home during demonstrations. 
www.indymedia.org) that, they argue, are purposefully ignored by corporate media providers. In doing so, Indymedia recognises the ways in which information flows are structured by the wider political economy and therefore contribute to a particular understanding of the world. It aims to offer an explicitly alternative understanding of the news and attempts to instigate change by circumventing the traditional editorial structures of the mainstream. The spaces on Indymedia are consequently open and less structured and as a result, Indymedia is open to a multiplicity of alternative and sometimes conflicting perspectives that constantly re-articulate various us/them distinctions (Ruiz, 2014).

In comparison, Sukey has a far less passionate, more distanced understanding of truth. Rather than recognising the contest between competing narratives that construct our understanding of events, Sukey focuses its energies on creating an information flow capable of channelling previously unavailable information into a shared narrative. In this way, Sukey aims to deliver information to members of the demonstrating public that will enable them to 'make sensible informed decisions' about the ways in which they engage with the legal limits previously specified by the police (http://www.opensukey.org). This is not to say that Sukey is uninterested in redressing the imbalance of information between protesters and police, but to point out that they do so by increasing the range of narrative flows rather than by directly challenging pre-existing narratives.

Sukey places great emphasis on the ways in which information is gathered, condensed and verified before being released back out on to the street:

When you see something interesting, you tell us. When we're confident that something has actually happened we tell you'. (http://www.opensukey.org).

Whereas Indymedia sees the representation of events on the ground as something which is in part constructed and contested within the discursive realm, Sukey presents events as something that can, and should, be verified by external observers before entering the discursive realm. According to this view, events are something that have either happened or not happened and Sukey perceives its role to be that of determining in which of these two categories a particular piece of information should fall. Consequently, one could describe Sukey's intervention as technological rather than ideological in its nature.

This conceptualization of information as true, verifiable and objective is an informational ethos, which Sukey team members acknowledge as having come straight from the mainstream newsroom: 'We're like a busy newsroom', says Bernie, 'we have to get information in, check it makes sense, and then get it back out' (Kingsley, 2011). This ethos is built upon a liberal conception of the public sphere in which the media both inform the public, and constitute a neutral power-free zone in which to agree upon what constitutes the greater good (Habermas, 1974). Sukey seeks to create a digital space in which protesters can share information and arrive at an informed collective consensus about the best ways in which to proceed. This strategy implies that balanced informational flows will provide users with a more complete understanding of events. In doing so, it backgrounds economic and social structural inequalities and effaces the power disparities between social actors.

Such an understanding contrasts with conceptualisations of the public sphere which regard conflict as both an inevitable and a necessary part of the democratic process (Mouffe, 2005). Consequently, radical democratic approaches allow for a perpetually shifting and more complex 
understanding of truth within the public sphere. Indymedia's refusal to verify information means that its pages are characterized by far more agonistic (and sometimes antagonistic) clashes of opinion. In this way, we can see that even though Sukey occupies a digitalized space routinely characterized as being constituted by empowering horizontal flows, it is, in comparison to Indymedia, actually rather didactic and hierarchical in its technical composition and communicative tone.

\section{...Sukey take it off again}

Sukey has garnered a considerable amount of generally positive mainstream media coverage. Articles prompted by Sukey's initial press release have appeared in The Economist, The Star and the New Scientist. A far longer article, drawing on a visit to the team's 'secret nerve centre', appeared in The Guardian shortly after the demonstrations on January 29 (Kingsley, 2011). All these articles outlined Sukey's basic aims and intentions and were cautiously optimistic about the opportunities offered by the new web application.

The response from the alternative media was initially similarly positive, with supportive articles and blogs appearing on sites such as Indymedia UK and Beyond Clicktivism. Sukey was recognised to be a 'nifty gadget' (Fox, 2011) with the potential to change the ways in which protesters and the police engaged with each other during public demonstrations. However, a perceived reluctance to fully engage with alternative publics prompted a shift in activists' responses to the web application. These doubts coalesced around Sukey's willingness to engage with mainstream organisations in general and the police in particular.

In February 2011 Sukey released a press statement entitled 'Sukey comments on today's HMIC report', which addressed the way in which the police force was struggling to 'cope with the increased volume and frequency of protest' in the wake of proposed cuts to their budget. It offered to 'step into that gap' by 'sharing information on planned kettles openly and honestly' and included the following statement:

Our work coincides entirely with the police goal of preserving public order, and the public's concern of staying safe at protests. It goes without saying that we are addressing concerns that we restrict criminals from exploiting it. (http://www.sukey.org)

This press release prompted a bitter and extended activist backlash, which made itself manifest through a flurry of frequently vitriolic outrage on Twitter and other social networking sites. The following month, minutes from a meeting between Sukey team members and the Metropolitan Police Service were leaked on Indymedia where they were described as 'not irredeemably damming' and 'smacking more of naivety than genuine collusion' (Riotact, 2011).

The Sukey team's willingness to engage with the police caused much consternation within the wider activist community. Many activists felt that Sukey had failed to understand the power dynamics between police and protesters within the public sphere and were highly critical of Sukey's tendency to categorize police and protesters as equally powerful partners in dialogue. This point is best exemplified by an activist who described the police as a 'massive conservative and powerful state institution which can legally use force and coercion' and argued that Sukey's emphasis on balance was failing to 'whole-heartedly take sides with those who hold the least power' (Random Blowe, 2011)

Activists' criticism quickly consolidated around three interwoven issues: Sukey's refusal 
to release the code behind the application to online activist communities; Sukey's reliance on commercial platforms; and Sukey's ongoing engagement with the police. These issues will now be discussed in such a way as to reveal the problematic assumptions which underpin Sukey's perception of protest, its role within city spaces and within the wider public sphere.

The first criticism was technological in its nature. While the Sukey team were prepared in principle to release the code to other protester organisations that had expressed an interest in replicating the application in different locations, they claimed that 'usability issues' (https:// london.indymedia.org.uk) prevented them from doing so. For example, the Sukey team maintained that the code would be 'meaningless to most without a decent and easy to use front and back end' (Gaus cited in Kinsley, 2011). When pushed, Sukey expressed its intent to release an annotated version of the code after the London demonstration 'then start working on Sukey 2 in a private fork' on the grounds that this would 'maximise both security and openness" (https:// london.indymedia.org.uk).

However, activists from autonomous traditions are generally happy to throw 'messy code out into the public domain' and felt that this was an act of technological gatekeeping (Harrison, http://visionon.tv, 2011). At a pragmatic level, it was pointed out that refusing to release the code prevented Sukey from crowd-sourcing technical skills which would enable 'holes to be found and fixed a lot faster' (Harmon, http://visionon.tv, 2011). On a more strategic level, it was argued that releasing the code would enable other activists to develop the code rhizomatically in any direction and so contribute to 'a diversity of strategies that is the building block of all successful social change projects' (Campell, http://visionon.tv, 2010). The most critical commentators maintained that Sukey's refusal to release the code stemmed from a desire to remain in 'complete control' in order to better 'collaborate with the police' (Harrison, http://visionon.tv, 2011).

The second criticism stems from the web application's occupation of commercial rather than alternative online spaces. The speed and intensity of technological change means that activists are frequently faced with a choice between remaining loyal to alt-tech and accepting 'the probably crippling effects of moving into a shadow world of limited usability/effectiveness' (Campbell, http://visionon.tv, 2011) or interacting with corporate sites which function 'on a scale and in a speed and with a user base that is huge compared to anything we ever did' (Indymedia London network cited in Askanius and Gustafsson 2010: 36). In these circumstances protest organisations are increasingly 'hopping the fence' and moving into online spaces with greater technological affordances (Lodge, http://visionon.tv, 2011).

As a result of these dynamics there has been a move from explicitly radical sites such as Indymedia and Alternet to online spaces that are owned and controlled by commercial organisations such as Facebook and Twitter. These changes in the media practices of activism create hybrid spaces that are characterised by 'the coexistence of subversive politics and commodified private communications' (Askanius and Gustafsson 2010: 23). Within such spaces, activists' passionate critiques of neo-liberalism are often surrounded by banner ads promoting the consumption patterns that underpin the self-same dynamic. Thus, while activists may be radical in their individual intent, these spaces are often politically ambiguous.

Sukey's uncertain position within these hybrid spaces is highlighted by its own use of language. Sukey rarely echoes the vocabulary and tone of the radical left. Instead, it tends to echo the consumption-orientated lexicon of the mainstream. For example, the Sukey team describe itself as a 'free product' (Sukey press release, 2011). Similarly, while Sukey distributes information about the movements of police and protesters, it also offers information about nearby amenities

6 Sukey has as yet to release the code, although it has been working with activists from Visionon TV. Following a period of silence it recently tweeted about a forthcoming collaboration with 'the most intuitive hackers/developers'. 
such as coffee shops, public conveniences and payphones (Sukey press release, 2011). Indeed, at times, their tone verges on the corporate. For example, its aims and intentions are outlined in 'an executive statement', where its 'objectives' and 'Success Criteria' are also carefully outlined (Indymedia, 2011).

Criticisms from the wider activist community were less concerned with the potentially commodified status and tone of these spaces and more alarmed by the security implications raised by the use of mainstream media platforms. For many activists, particularly those engaged in more confrontational forms of direct action, this is, of course, deeply problematic. As recent revelations regarding the infiltration of protest groups by the Special Demonstration Squad illustrate, many activists' lives are already far too heavily policed. This is a view expressed by the Indymedia activist Yossarian, who claims that occupying mainstream online spaces, such as Twitter and Facebook, is 'like holding all your political meetings at McDonalds and ensuring that the police come and film while you do so' (cited in Askanius and Gustafsson, 2010: 34).

Despite these very real fears, the opportunities offered by mainstream service providers mean that activists simply cannot afford to ignore mainstream platforms such as Facebook or Twitter. Having decided to utilise mainstream platforms, Sukey took these issues seriously from the onset and ensured that all its data was 'anonymised using secure encryption that is known to be unbreakable in less than ten years using current computer technology' (spyblog.org.uk). Unfortunately, these unsubstantiated reassurances were given so late and so lightly that the web application's 'reputation and credibility' (Gaus cited in Kingsley, 2011) within the wider activist community had already been severely compromised.

Sukey's reluctance to release their coding, and their use of commercial platforms is indicative of the web application's ambiguous position on the boundary that both separates and connects the margins from/to the mainstream. This brings us to the wider activist community's third criticism of Sukey: its attitude to the mainstream in general and the police in particular. Sukey's willingness to engage with journalists and the police signals a shift away from an alternative/ oppositional dichotomy outlined in relation to Indymedia and towards a less explicitly critical view of the mainstream. This understanding can be most clearly heard in one of Sukey's responses to criticism from the wider activist community. It reads:

I think we have a different perception between our target audiences/readers ... Sukey is about keeping peaceful protesters safe and informed and mobile. We're not part of the anarchist toolkit - and nor do we want to be ... Sukey is designed to be predominately mainstream. (http://visionon.tv)

Thus, while Sukey may well be critical of specific governmental policies, it is not critical of the mainstream per se. Indeed Sukey perceives itself to be the mainstream.

This conceptualisation of protesters does not challenge or unsettle the distinctions commonly drawn between protesters and publics. Indead, Sukey simply relocates this boundary by redefining protesters as 'not full time activists' and re-conceiving them as 'just normal people who want to go about their normal lives'. Thus, Sukey appears to elide the category of public and protester within the notion of the 'predominantly mainstream'. However these normal, mainstream people are contrasted with 'the crazies' or 'criminals' (http://visionon.tv) who actively seek confrontation with the apparatuses of state. Consequently, one could argue that Sukey is simply reproducing the distinctions commonly imposed by the police on the ground and journalists in the papers between 'good' protesters and 'bad' protesters. 
The distinction drawn by Sukey is particularly problematic in that it emerges from within a protest movement rather than being imposed upon a protest movement by external forces. Like an externalised solar eye, it stills the 'opaque mobility' of contemporary protest movements, smoothes out the contradictions and conflicts and offers the reader an apparently 'transparent text' (de Certeau, 1984: 93). However, the sense of unity is a 'fiction', a 'semblance', which many activists felt contributed towards, rather than resisted, the administration of autonomous protest by the state. This was particularly so for those activists who perceive the role of radical politics to be that of making unnoticed power dynamics visible so that they may enter the terrain of contestation (Karppinene, 2007).

Alternative media sites such as Indymedia have attempted, with varying degrees of success, to maintain solidarity across the boundaries that have been used by the mainstream to distinguish 'good' protesters from 'bad' protesters (Ruiz 2014). However, the distinction drawn by Sukey ignores the possibility of solidarity between differently orientated protest clusters and is therefore entirely in keeping with more mainstream representations of activists. This was a view that was quickly taken up and articulated within the wider activist community, which accused Sukey of 'buying into the mass media and the government's line on what kind of protest is acceptable' (Steve, 2011).

At the core of the debate between the newly politicised students at Sukey and activists whose politics have been shaped by more autonomous traditions is a series of questions about the role of conflict within political protest. Sukey is firmly rooted in a liberal tradition that works towards the eradication of the boundaries between different social actors such as police and protesters. However, Sukey's desire to reduce 'the need for kettling' (http://www.openSukey.org) is deeply problematic for activists who consider that 'mass violence against the police is a necessary part of any social struggle' (http://thecommune.co). Thus, whilst Sukey adopts a very Habermasian position in which conflict is seen as evidence of a failure of the political system, many members of the wider activist community see conflict as a necessary and potentially productive element in the creation of social and political change (Mouffe, 2005).

As discussed at the start of this article, protest organisations have traditionally used mass demonstrations to show the strength of their commitment and recruit fresh supporters. Rising levels of civil unrest combined with diminishing levels of public funding mean that the role played by conflict during such public demonstrations is increasingly crucial. The arrival of politically marginal groups into shared public space upsets the pre-existing social order. Protesters attending mass demonstrations arrive in the city seeking permanent change. They want their views, which have been defined by the status quo as marginal, to become mainstream. This transition from the edge to the centre is uncertain and contingent. However, as this case study demonstrates, the mainstreaming of protest introduces a new set of dynamics that more established activist communities are still attempting to comprehend.

Sukey offers protesters a solar eye view of autonomous demonstrations as they unfold upon the ground. It is designed to enable 'normal people' (http://www.openSukey.org) to avoid being kettled by the police. However, it uses new communications technologies to ease friction between protesters and police in a way which activists from an autonomous tradition perceive as problematic. This is because, in collapsing the boundary between protesters and police, it creates a new (and far more familiar) boundary between activists and protesters, normals and crazies, the mainstream and the margins. Consequently, the disengaged or distanced view offered by Sukey's solar eye could be seen as contributing to, rather than resisting, the administration of autonomous protest.

If protesters are criminals rather than citizens, bad rather than good, then any action against 
them becomes an action taken in the public interest. In this article I have examined the ways in which different ways of experiencing the city and different ways of using new information technologies contribute to the formation of us/them dynamics. In doing so, I have explored the practices of kettling and the practice of maptivism in order to reflect upon Sukey's ability to resist the totalising administrations of the state. However, I have found that Sukey's articulation of us/then distinctions confirms, rather than challenges, mainstream understanding of protest and contributes to a dynamic in which the de-legitimisation of protesters justifies the use of state force. 


\section{References}

Amartrudo, A. (2009) Criminology and Political Theory, London: Sage.

Askanius, T. and Gustafsson, N. 2010 'Mainstreaming the Alternative: The changing media practices of protest movements', Interface; a journal for and about social movements, Vol. 2 pp. 23-41.

Benkler, Y. (2006) The Wealth of Networks; How social production transforms markets and freedoms, New Haven CT: Yale University Press.

Bennet, L. and Segerberg, A. (2012) 'The logics of connective action: Digital media and the personalisation of contentious politics', Information Communication and Society, Vol. 15 pp. 739-768.

Black block protestors (no date) 'Genoa beyond the hype', http://flag.blackened.net/revolt/ freeearth/genoa_hype.html [1st October 2009].

Bowcott, O. (2011) 'Met police kettled pupils aged 11 during fee protests, court told', The Guardian, Tuesday 5 July, http://www.guardian.co.uk/ uk/2011/jul/05/met-police-kettling-childrenhigh-court [1 ${ }^{\text {st }}$ July 2013].

Brighton and Hove Argus (2005) 'Anti-war protesters converge on city', 11th June, http://www. archive.theargus.co.uk/2005/10/6 [2nd July 2009].

Castells, M. (2007) 'Communication, Power and Counter Power in the Networked Society', International Journal of Communication, Vol. 1 pp 238-266.

HMSO (1994) 'Criminal Justice and Public Order Act' http://www.opsi.gov.uk/acts/acts1994/ ukpga_19940033_en_1 [14 ${ }^{\text {th }}$ December 2009]

The Commune (2010) 'On Violence Against the Police', http://thecomune. co.uk/2010/12/10/on-violence-against-thepolice/[1 ${ }^{\text {st }}$ of July 2013].

Council of Europe (2010) 'European Convention of Human Rights', http://www.echr.coe.int/ Documents/Convention_ENG.pdf [ $28^{\text {th }}$ Oct 2013].

De Certeau, M. (1984) The Practice of Everyday Life, Berkeley: University of California Press.

Donson, F. Chester, G. Welsh, I Tickle, A. (2004) 'Rebels with a cause, Folk devils without a panic: press jingoism, policing tactics and anti-capitalist protest in London and Prague', Internet Journal of Criminology.
Douglas, M. (2002) Purity and Danger: An analysis of concepts of pollution and taboo, London and New York: Routledge.

Fox, D. (2011) 'Double lyric', http://codepoetics. com/octoblog/blog/2011/02/10/doublelyric/ [1 ${ }^{\text {st }}$ July 2013].

Fraser, N. (1990) 'Re-thinking the public sphere: a contribution to the critique of actually existing democracy', Social Text, Vol. 8-9 pp.56-80.

Gitlin, T. (2003) The Whole World is Watching: Mass Media in the Making and the unmaking of the New Left, Berkeley: University of California Press.

Graeber, D. (2004) 'The new anarchists', in Mertes, T. (ed.) A Movement of Movements, London: Verso.

The Guardian (2009) 'Police caught on tape trying to recruit Plane Stupid protester as spy', 21st April, http://www.guardian.co.uk/uk/2009/ apr/24/strathclyde-police-plane-stupidrecruit-spy [15th May 2009].

The Guardian (2009) 'Police paid informants $£ 750,000$ in four years', 8th May, http:// www.guardian.co.uk/politics/2009/may/08/ strathclyde-police-informant-payments $\quad[15$ th May 2009].

Habermas, J. (1974) 'The public sphere: an encyclopaedia article', New German Critique, Vol. 3 pp.49-55.

Hall, S. (1974/1980) 'Encoding and Decoding', Abridged version reproduced in Nightingale, V. \& Ross, K. (eds) Critical readings: Media and Audiences. Maidenhead: Open University Press.

Halloran, J. Elliott, P. and Murdock, G. (1970) Demonstrations and Communications: A Case Study, London: Penguin.

Hardy, T. (2011) 'Polly put the kettle on, Sukey take it off again' http://beyondclicktivism. com/2011/01/27/polly-put-the-kettle-onsukey-take-it-off/ [1 ${ }^{\text {st }}$ July 2013].

Her Majesty's Inspectorate of Constabulary (2011) 'Policing Public Order', http://www.hmic.gov. uk/media/policing-public-order-20110208. pdf [1 $1^{\text {st }}$ June 2013].

Juris, J. (2005) 'Violence performed and imagined: militant action, the black block and the mass media in Genoa', Critique of Anthropology, Vol. 25 no. 4 pp. $413-432$.

Karppinen, K. (2007) 'Against Naïve Pluralism in Mediated Politics: On the implications of radical pluralistic approaches to the public 
sphere', Media Culture and Society, Vol. 29 pp. 495.

Kingsley, P. (2011) 'Inside the anti-kettling HQ', The Guardian, Thursday 3 February, http://www. guardian.co.uk/uk/2011/feb/02/inside-antikettling-hq [ $1^{\text {st }}$ of July2012].

Latour, B. (1999) 'On Recalling ANT', in Law, J. \& Hassard, J. (eds). Actor Network Theory and After, (pp. 15-25) Malden, MA: Blackwell.

McAdam, D. (1999) Political Process and the Development of Black Insurgency, 1930-1970, Chicago: University of Chicago Press.

Moles, K. (2008) 'A Walk in Thirdspace: Place, Methods and walking', Sociological Research Online, Vol. 13 (4) 2 np.

Mouffe, C. (2005) On the Political, London and New York: Routledge

Notes from Nowhere (ed), (2003) We Are Everywhere: The irresistible rise of global anti- capitalism, London: Verso.

Ong, W. (1982) Orality and Literacy: The Technologising of the Word, London and New York: Methuen.

Patton, P. (2000) Deleure and the Political, London and New York: Routledge.

Random Blowe (2011) http://www.blowe.org. uk/2011_02_01_archive.html [1 ${ }^{\text {st }}$ July 2013].

Reiner, R. (1998) 'Policing, protest and disorder', Della Porta, D. and Reiter, H. (eds) Policing Protest: The Control of Mass Demonstrations in Western Democracies, University of Minnesota Press: Minneapolis.

Reiner, R (2000) The Politics of the Police, Oxford: Oxford University Press.

Rheingold, H. (2004) 'Smart mobs', in McCarthy, H. Miller, P. and Skidmore, P.(eds) Network Logic; who governs in an interconnected world, London: Demos.

Riotact (2011) 'Will Sukey Keep Us Safe? ... Leaked Minutes Reveal Cosy Chats With Met', $22^{\text {nd }}$ March, http://www.indymedia.org.uk/ en/2011/03/476391.html [9 $9^{\text {th }}$ June 2014].

Routledge, P. (1996) 'The Third Space as Critical Engagement', Antipode, Vol. 28 (4) pp. 399419.

Ruiz, P. (2008) 'Walking the net: An exploration of alternative media and smooth space', Ross, K. \& Price, S. (eds) Popular Media and Communication, Newcastle: Cambridge Scholars Publishing, pp. 168-190.

Ruiz, P. (2014) Articulating Dissent: Protest and the Public Sphere, London: Pluto Press.
Soja, E. (1996) Thidspace: Journeys to Los Angeles and Other real-and-Imagined Places, Oxford, Basil Blackwell.

Stein, L. (2001) 'Social movement web use in theory and practice: a content analysis of US movement websites', New Media and Society. Vol.11 pp. 749-771.

Sukey http:/ /www.opensukey.org [1 ${ }^{\text {st }}$ of July 2013]

Sukey sucks, Libcom.org http://libcom.org/ forums/general/sukey-sucks-09022011 [1 ${ }^{\text {st }}$ of July 2013]

Sukey (2011) 'Live demo info service for saturday', Indymedia, -ldn--https://london.indymedia.org. uk/articles $/ 7065$

Sukey - peaceful protest App without any mobile phone network Communications Data or Traffic Data anonymity Spyblog January 29, 2011 https://p10.secure.hostingprod.com/@ spyblog.org.uk/ssl/spyblog/2011/01/29/ sukey--protest-app-without-any-mobilecommunications-data-anonymity.html $\left[1^{\text {st }}\right.$ of July 2013].

Unnamed protester. J18 (1999) 'Our resistance is as transnational as capital', www.network23. nologic.org/trapese/cdrom/contents / context $/$ txts $/$ past $\% 20$ mobilisations $/ \mathrm{j} 18$.htm [1st October 2009]

Van Zoonen, L. (2004) Entertaining the Citizen: When politics and popular coverage converge, New York: Rowman and Littlefield.

Viner, K. (2000) “Luddites" we should not ignore', Guardian, 29th September, http:/ / www.guardian.co.uk/Archive/ Article / 0,4273,4069644,00.html [4th February 2004].

Visionon TV (no date) http://visionon.tv/ forum/-/message_boards/e/944806;jsession $\mathrm{id}=4$ AC84D2E0D6480F9B972E2BB82188A $4 \mathrm{~F}$ [9 $9^{\text {th }}$ June 2014.]

Waddington, P.A. J. (1998) Policing Citizens: Police, Power and the State, London and New York: Routledge. 